\title{
9. MIDDLE CRETACEOUS OSTRACODES FROM LEG 101, HOLES 627B AND 635B, BAHAMAS ${ }^{1}$
}

\author{
Renée Damotte ${ }^{2}$
}

\begin{abstract}
In Cores 101-627B-38X, -627B-39X, -627B-43X, -627B-46X, -627B-47X, and in Core 101-635B-14R, 10 species of ostracodes were found, all of which originally were described as being late Albian-Cenomanian from occurrences in the southeastern United States: Cytherella austinensis, Cythereis (Cythereis) fredericksburgoides, Cythereis (C.) cf. pittensis, Cythereis (Rehacythereis) simunoluda, Cytheropteron (Eocytheropteron) jugosum (very rare), Isocythereis(?) sp., Protocythere alexanderi, Protocythere paratriplicata, Pterygocythereis cf. tokiana, and Schuleridea washitaensis. This assemblage indicates an outer neritic environment.
\end{abstract}

\section{INTRODUCTION}

Examination of middle Cretaceous ostracodes from Leg 101, Hole 627B (north of Little Bahama Bank), and Hole 635B (Northeast Providence Channel), revealed rather poor faunas. Seven genera were found. Cythereis, Isocythereis, and Protocythere are classical Cretaceous genera, whereas Cytherella, Schuleridea, Cytheropteron, and Pterygocythereis show a wider stratigraphic range. In Cores 101-627B-38X, -627B-39X, -627B-43X, $-627 \mathrm{~B}-46 \mathrm{X}$, and -627B-47X, the association is similar: Cytherella austinensis, Cythereis (Cythereis) fredericksburgoides, $C y$ thereis (C.) cf. pittensis (rare), Cythereis (Rehacythereis) simunoluda, Cytheropteron (Eocytheropteron) jugosum (very rare), Isocythereis(?) sp. (rare), Protocythere alexanderi, Protocythere paratriplita, and Pterygocythereis cf. tokiana. In Core 101-635B14R, only Cytherella austinensis and Cythereis (C.) fredericksburgoides are present. A selection of ostracode samples is shown in Plates 1 and 2.

\section{STRATIGRAPHIC INTERPRETATION}

The stratigraphic interpretation presented here is based on the occurrences of ostracodes in North America, especially in the southeastern United States. The species observed in this study are not found in Europe. American authors generally refer to local formations for the stratigraphic ranges of ostracodes. Correlations with the international stages are difficult, and I mainly use Swain's correlation tables (1985, Figs. 1 and 2).

\section{Hole 627B}

In Samples 101-627B-38X-5, 50-52 cm, and 101-627B-38X-6, 50-52 cm, the presence of Protocythere alexanderi, Protocythere paratriplicata, and very rare Cytheropteron (E.) jugosum indicates a Cenomanian age. In Samples 101-627B-39X-1, 50-52 $\mathrm{cm}$, and 101-627B-39X-5, 50-52 cm, Protocythere paratriplicata and Schuleridea washitaensis were observed. In Sample 101-627B-39X-3, 50-52 cm, in addition to the latter two species, Cytherella austinensis, Cythereis (C.) fredericksburgoides, $C y$ thereis (C.) simunoluda, and Protocythere alexanderi also occur, indicating the Cenomanian. Sample 101-627B-43X-3, 15$17 \mathrm{~cm}$, contains Cytherella austinensis, Cythereis (C.) fredericks-

\footnotetext{
${ }^{1}$ Austin, J. A., Jr., Schlager, W., et al., 1988. Proc. ODP, Sci. Results, 101: College Station, TX (Ocean Drilling Program).

2 Unité associée au Centre National de la Recherche Scientifique No. 319 et Laboratoire de Micropaléontologie de l'Université Pierre et Marie Curie, Paris $\mathrm{V}^{\circ}$, France.
}

burgoides, Cythereis (C.) simunoluda, Protocythere alexanderi; in Sample 101-627B-43X-4, 50-53 cm, only Cythereis (C.) simunoluda and Schuleridea washitaensis occur. These species indicate a Cenomanian age for Core 101-627B-43X. In Sample 101-627B-46X-5, 50-53 cm, I found Cythereis (C.) fredericksburgoides, Cythereis (C.) simunoluda, Cytherella austinensis, and also Pterygocythereis cf. tokiana, which ranged from Aptian to Turonian time, but the rest of the fauna suggests a Cenomanian age for Core 101-627B-46X. In Sample 101-627B-47X-5, $50-52 \mathrm{~cm}$, a Cenomanian association is present, including Cytherella austinensis, Cythereis (C.) fredericksburgoides, Protocythere paratriplicata, and Schulderidea washitaensis. In Section 101-627B-53X, CC Schuleridea washitaensis is the only species present, which indicates a late Albian or Cenomanian age for this sample.

\section{Hole 635B}

In Sample 101-635B-14R-3, 146-148 cm, the association is limited to Cytherella austinensis and Cythereis (C.) fredericksburgoides, suggesting a Cenomanian age.

Correlations with biostratigraphic results from calcareous nannofossils and planktonic foraminifers (Shipboard biostratigraphic results, Austin, Schlager, et al., 1986) are as follows.

Calcareous nannofossils are characteristic of the Lithraphidites acutum Zone, middle to late Cenomanian, in Cores 101627B-37X and -627B-38X, which agrees well with the Cenomanian age indicated by ostracodes. The Eiffellithus turriseiffeli Zone is present in Cores 101-627B-39X through 101-627B-49X, indicating a late Albian to middle Cenomanian age, but "the primitive nature of the eiffellithids and prediscosphaerids in the basal part of the cored sequence, as well as the absence of C/orollithion] kennedyi from Cores 627B-45X through 627B-49X, suggests that this interval is no younger than the earliest Cenomanian" (Austin, Schlager, et al., 1986, p. 127). A similar age is suggested by planktonic foraminifers in Cores 101-627B-37X through 101-627B-49X: "A latest Albian to early Cenomanian age is suggested for Cores 101-627B-45X to -627B-47X based on the co-occurrence of Rotalipora gandolfii and $R$. appenninica. The absence of Planomalina buxtorfi suggests an early Cenomanian age, although environmental exclusion from a neritic environment may be a viable explanation" (Austin, Schlager, et al., 1986). Ostracodes also indicate a Cenomanian age for all these cores. Shipboard study of benthic foraminifers indicates an Albian age for Core 101-627B-53X, which agrees with ostracode data.

The presence of Biticinella breggiensis in Core 101-635B-14R indicates a late Albian (Vraconian) age, but ostracode species in this core generally are no younger than Cenomanian. 


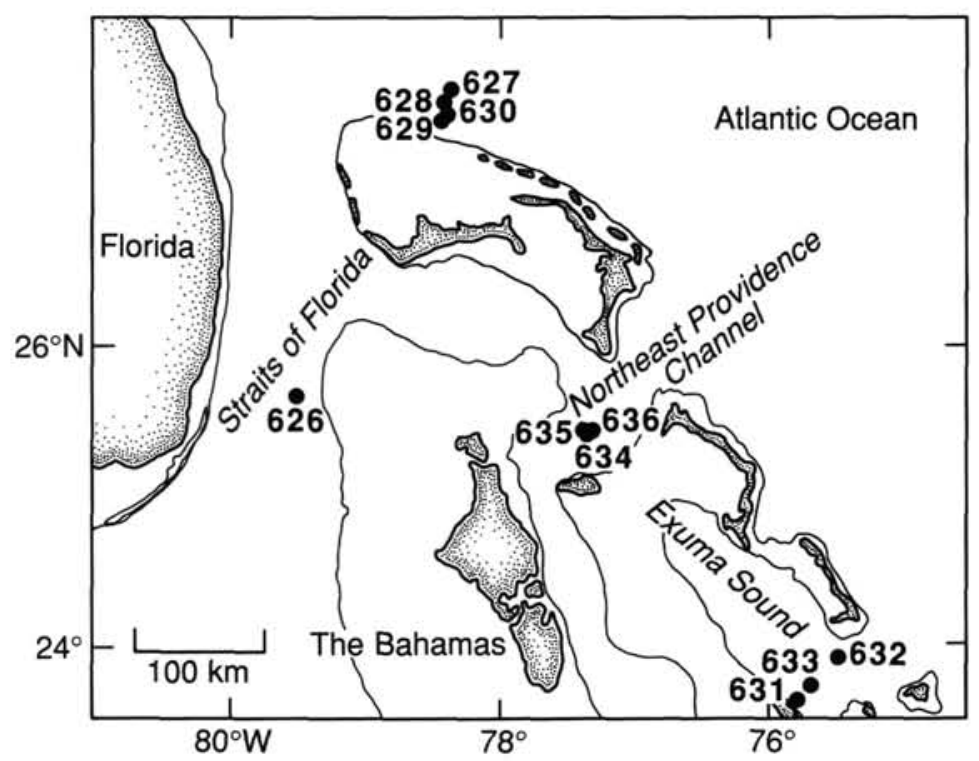

Figure 1. Location map of Leg 101.

\section{ECOLOGICAL INTERPRETATION OF OSTRACODE ASSEMBLAGES}

In Cores 101-627B-38X through -627B-47X, the association of Trachyleberididae (Cythereis, Protocythere, and Pterygocythereis) indicates a circalittoral environment in an outer neritic province. These forms possess an eye tubercle and lived in the photic zone (generally between 0 and $200 \mathrm{~m}$ in depth). In Section 101-627B-53X, CC the fauna is restricted to the genus Schuleridea, suggesting the inner neritic province.

Shipboard studies of planktonic foraminifers suggest that the depositional setting of Hole 627B gradually changed from a neritic (Core 101-627B-49X) to an outer neritic environment (Core 101-627B-37X) (Austin, Schlager, et al., 1986). The benthic foraminifers indicate a shallow-water, back-reef environment in Core 101-627B-53X. This interpretation agrees well with the ostracode data.

In Core 101-635B-14R, the ostracode fauna is composed of Cytherella and Cythereis and suggests an outer neritic deposit (as seen in Hole 627B), except for Core 101-627B-53X.

\section{SYSTEMATIC DESCRIPTIONS}

\author{
Subclass OSTRACODA Latreille, 1806 \\ Order PODOCOPIDA Sars, 1866 \\ Suborder PLATYCOPINA Sars, 1866 \\ Family CYTHERELLIDAE Sars, 1866 \\ Genus CYTHERELLA Jones, 1849
}

Cytherella austinensis Alexander, 1929

$$
\text { (Pl. 1, Figs. 1-3) }
$$

Cytherella austinensis Alexander, 1929, p. 51, Pl. 2, Figs. 4-6 (male fide Howe and Laurencich, 1958, p. 244).

Cytherella obesa Alexander, 1929, p. 51, Pl. 1, Figs. 3-6 (not Jones and Kirkby, 1884) (female fide Howe and Laurencich, 1958, p. 244).

Cytherella cf. obesa Alexander, Swain, 1952, p. 68, Pl. 8, Fig. 2.

Cytherella austinensis Alexander, Swain and Brown, 1964, p. 9, Pl. 1, Figs. 2a-d.

Length. $0.60-0.57 \mathrm{~mm}$.

Occurrences. This species was described by Alexander (1929) from the Austin Formation of Texas (first attributed to the Coniacian-Santonian). Swain (1952) found the species in the Peedee Formation of North Carolina (Late Cretaceous). In Georgia and Florida, Swain and Brown (1964) found Cytherella austinensis in the lower member of the Atkin- son Formation, which they correlated with the Woodbine Formation of Texas. Swain (1985) classified the Woodbine Formation as Cenomanian (not basal Cenomanian).

Occurrences in Leg 101. See Table 1.

Suborder PODOCOPINA Sars, 1866

Family CYTHERIDEINAE Sars, 1925

Subfamily CYTHERIDEINAE Sars, 1925

Genus SCHULERIDEA Swartz and Swain, 1946

Schuleridea washitaensis (Alexander, 1929)

$$
\text { (Pl. 1, Figs. 4-6) }
$$

Cytheridea washitaensis Alexander, 1929, p. 71, Pl. 4, Figs. 12-14. Schuleridea washitaensis (Alexander), Swain and Brown, 1964, p. 23, Pl. 2, Figs. 9a-e.

Length. $0.77-0.68 \mathrm{~mm}$.

Occurrences. This species was described by Alexander (1929) from the Grayson Formation of Texas, probably late Albian-early Cenomanian. Swain and Brown (1964) found it in the lower member of the Atkinson Formation (Cenomanian).

Occurrences in Leg 101. See Table 1.

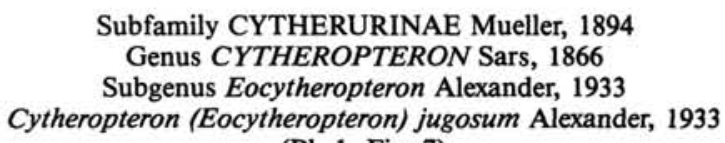

(PI. 1, Fig. 7)

Cytheropteron (Eocytheropteron) jugosum Alexander, 1933, p. 198, Pl. 27, Figs. 12a-b.

Length. $0.61 \mathrm{~mm}$.

Remarks. The specimen found here shows the external features described by Alexander (1933). The deep ventral furrow is clearly visible; in the ventral view, the five fine longitudinal ridges are present. The lateral surface of the valves is slightly reticulate and not as strong as reported by Alexander (1933). The internal characteristics were not observed.

Occurrences. Cytheropteron (E.) jugosum is described from the Denton Clay member of the middle part of the Washita Formation. The Washita Formation can be correlated with the late Albian-early middle(?) Cenomanian; thus, the Denton Clay is probably of early(?) Cenomanian age.

Occurrences in Leg 101. See Table 1. 
Table 1. Occurrences of ostracodes, Holes 627B and 635B.

\begin{tabular}{|c|c|c|c|c|c|c|c|c|c|c|c|}
\hline Samples (cm) & 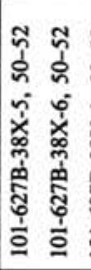 & 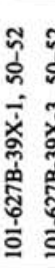 & 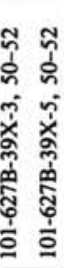 & 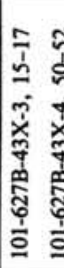 & 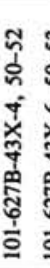 & 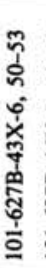 & 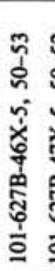 & 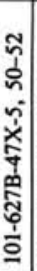 & 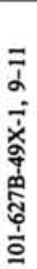 & 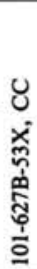 & 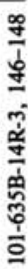 \\
\hline $\begin{array}{l}\text { Protocythere alexanderi } \\
\text { Protocythere paratriplicata } \\
\text { Isocythereis(?) sp. } \\
\text { Cytheropteron (E.) jugosum } \\
\text { Schuleridea washitaensis }\end{array}$ & $\because \bullet$ & - & $\bullet$ & $\bullet$ & & & $\bullet$ & $\bullet$ & & & \\
\hline $\begin{array}{l}\text { Cytherella austinensis } \\
\text { Cythereis }(C .) \text { fredericksburgoides } \\
\text { Cythereis (R.) simunoluda } \\
\text { Pterygocythereis cf. tokiana } \\
\text { Cythereis }(C .) \text { cf. pittensis }\end{array}$ & $\bullet$ & $\bullet$ & - $\bullet$ & $\bullet$ & • & $\bullet$ & • & & & & \\
\hline
\end{tabular}

Family TRACHYLEBERIDIDAE Sylvester-Bradley, 1948

Genus CYTHEREIS Jones, 1849

Subgenus Cythereis Jones, 1849

Cythereis (Cythereis) fredericksburgoides Swain and Brown, 1964 (Pl. 1, Figs. 8-11)

Cythereis (C.) fredericksburgoides Swain and Brown, 1964, p. 34, Pl. 3, Figs. 9a-f.

Length. $0.77-0.68 \mathrm{~mm}$.

Remarks. The specimens found in these samples seem similar to Cythereis (C.) fredericksburgoides, but the longitudinal ridges are narrower than those described by Swain and Brown (1964).

Occurrences. This species was described from the lower member of the Atkinson Formation of Georgia and Florida of Cenomanian (not basal Cenomanian) age.

Occurrences in Leg 101. See Table 1.

Cythereis (Cythereis) cf. pittensis Swain and Brown, 1964 (Pl. 1, Fig. 12)

Cythereis pittensis Swain and Brown, 1964, p. 29, Pl. 3, Figs. 7a-b.

Length. $0.65 \mathrm{~mm}$.

Remarks. Only one specimen was found; it seems similar to Cythereis pittensis. In our form the anteroventral angle is more elevated, and the ventral ridge is divided into two close ridges.

Occurrences. Cythereis pittensis was described in North Carolina, probably from rocks equivalent to the Washita Formation, late AlbianCenomanian.

Occurrences in Leg 101. See Table 1.

\section{Subgenus Rehacytheris Gruendel, 1973 \\ Cythereis (Rehacythereis) simunoluda Swain, 1952}

(Pl. 2, Figs. 1-3)

Cythereis simunoluda Swain, 1952, p. 83, Pl. 9, Figs. 32-34.

Length. $0.77-0.80 \mathrm{~mm}$.

Occurrences. Swain (1952) described this species from the Eagle Formation (Cenomanian or Turonian) and from the equivalents of the Tuscaloosa Formation (Cenomanian) in North Carolina.

Occurrences in Leg 101. See Table 1.

\section{Genus PROTOCYTHERE Triebel, 1938}

Protocythere alexanderi Howe and Laurencich, 1958 (Pl. 2, Figs. 4-6)

Cythere triplicata Alexander, 1929, p. 79, Pl. 6, Figs. 2, 8.

Protocythere alexanderi Howe and Laurencich, 1958, p. 472.

Length. 0.49-0.55 $\mathrm{mm}$.

Remarks. On our specimens the middle ridge is clearly united to the dorsal ridge by a vertical rib. This vertical rib was indicated in Howe and Laurencich's (1958) description but was not visible in their drawing of the species.
Occurrences. Alexander (1929) described this species from the Grayson Marl of Texas. The Grayson Marl constitutes the upper part of the Washita Formation (Alexander, 1929); this Washita unit belongs to the late Albian and early Cenomanian (Swain, 1985). Thus, the typical level of Protocythere alexanderi seems to be Cenomanian, not Albian, as Howe and Laurencich (1958) reported.

Occurrences in Leg 101. See Table 1.

\section{Protocythere paratriplicata Swain, 1952}

$$
\text { (P1. 2, Figs. 7-9) }
$$

Protocythere paratriplicata Swain, 1952, p. 85, Pl. 9, Figs. 18-21.

Length. $0.59-0.62 \mathrm{~mm}$.

Occurrences and remarks. Swain (1952) described this species from equivalents of the Tuscaloosa Formation (Cenomanian) in North Carolina, and from the Black Creek Formation (Late Cretaceous, Senonian?). However, the genus Protocythere disappeared during the Cenomanian; thus, its presence in sediments of Senonian age is anomalous. From its general external features, this species also could belong to the genus Veenia, an Upper Cretaceous genus. Internal characteristics were not observed in this study, nor by Swain (1952).

Occurrences in Leg 101. See Table 1.

\section{Genus PTERYGOCYTHEREIS Blake, 1933}

Pterygocythereis cf. P. tokiana (Israelsky, 1929) sensu Swain, 1952

$$
\text { (Pl. 2, Figs. 10, 11) }
$$

Cytheropteron tokiana Israelsky, 1929, p. 9, Pl. 1A, Figs. 8, 9.

Pterygocythereis cf. P. tokiana (Israelsky), Swain, 1952, p. 85, Pl. 9, Figs. 1-3.

Alatacythere tokiana (Israelsky), Swain and Brown, 1964, p. 29, Pl. 3, Fig. 4.

Length. 0.93-0.99 mm.

Remarks. Our specimens are similar to Swain's (1952, Pl. 9, Fig. 1) but show a more rounded posterodorsal angle. The descriptions given by Israelsky (1929) and Swain (1952) agree well with other characteristics of the specimens found in this study. As the internal features were not observed, the species may belong to Pterygocythereis (Swain, 1952) or to Alatacythere (Swain and Brown, 1964); because of its external features, the species is provisionally placed in Pterygocythereis.

Occurrences. Swain (1952) found this form in Trinity and pre-Trinity formations (probably Aptian-Albian) and in the Eagle Formation (Cenomanian-Turonian) in North Carolina. According to Swain and Brown (1964), Alatacythere tokiana is present in the upper member of the Atkinson Formation (Cenomanian).

Occurrences in Leg 101. See Table 1.

Genus ISOCYTHEREIS Triebel, 1940

Isocythereis(?) sp.

(Pl. 2, Fig. 12)

Length. $0.68 \mathrm{~mm}$.

Description. Shell, small, subquadrate, higher near anterior end than elsewhere. Dorsal margin nearly straight; ventral margin also straight. Anterior margin broadly rounded; ornamented with small spines ventrally. Posterior margin pointed. Dorsal ridge has a strong spine at the posterior end. Ventral ridge spinose, with a larger spine at the posterior end. Median ridge slightly indicated by two or three spines. Surface reticulate with some small spines. Internal features were not observed.

Remarks. Based on external features, this form may belong to the genus Isocythereis, but the subcentral tubercle is not clearly visible, and the internal characteristics are unknown. However, this form may belong to the genus Trachyleberidea.

Occurrences in Leg 101. See Table 1.

\section{CONCLUSIONS}

The Cenomanian age determined in this study of ostracodes agrees with shipboard results from calcareous nannofossils and planktonic foraminifers. The only discrepancy is with Core 101635B-14R, which (based on the presence of the foraminifer Biticinella breggiensis) would belong to the upper Albian but contains two ostracode species no younger than Cenomanian. 


\section{R. DAMOTTE}

In Hole 627B, the inner neritic depositional setting (Core 101-627B-53X) changes to an outer neritic environment (Cores 101-627B-47X through 101-627B-38X). In Hole 635B, the ostracode assemblage (Core 101-635B-14R) also suggests an outer neritic deposit.

In Hole 627B, the upper Albian carbonate platform underlies the neritic Cenomanian facies, which contains ostracodes that are the same as those found in the lower part of Hole 635B (Core 101-635B-14R).

\section{ACKNOWLEDGMENTS}

I thank the staff of the Ocean Drilling Program for the opportunity to study samples from Leg 101. I am greatly indebted to E. Fourcade for providing samples from Leg 101 and for his critical reading of the manuscript. In addition, J. A. Austin, Jr., H. J. Oertli, A. A. Palmer, A. Rosenfeld, W. Schlager, D. Van Harten, and an anonymous reviewer reviewed the manuscript.

\section{REFERENCES}

Alexander, C. I., 1929. Ostracodes of the Cretaceous of North Texas. Univ. Texas Bull., 2907:1-137.

1933. Shell structure of the ostracode genus Cytheropteron and fossil species from the Cretaceous of Texas. J. Paleontol., 7(2): 181-214.
Austin, J. A., Jr., Schlager, W., et al., 1986: Proc. ODP, Init. Repts., 101.

Howe, H. V., and Laurencich, L., 1958. Introduction to the Study of Cretaceous Ostracoda: Baton Rouge (Louisiana State Univ. Press).

Israelsky, M. C., 1929. Upper Cretaceous Ostracoda of Arkansas. Arkansas Geol. Surv. Bull., 2:1-28.

Neale, J. W., 1977. Cretaceous Ostracoda of the North Atlantic Basin. In Swain, F. M. (Ed.), Stratigraphic Micropaleontology of Atlantic Basin and Its Borderlands: Amsterdam (Elsevier), 245-270.

Swain, F. M., 1952. Ostracoda from wells in North Carolina-Part 2: Mesozoic Ostracoda. U.S. Geol. Surv. Prof. Pap., 234B:55-93. 1985. Some Ostracoda from the Rodessa, Pearsall, Sligo and upper Hosston Formations (Lower Cretaceous of Louisiana, U.S.A.) Rev. Micropaléontologie, 27:266-294.

Swain, F. M., and Brown, P. M., 1964. Cretaceous Ostracoda from wells in the Southeastern United States. North Carolina Dept. Cons. Devel. Bull., 78:1-56.

Date of initial receipt: 25 April 1986

Date of acceptance: 17 December 1986 Ms 101B-121 


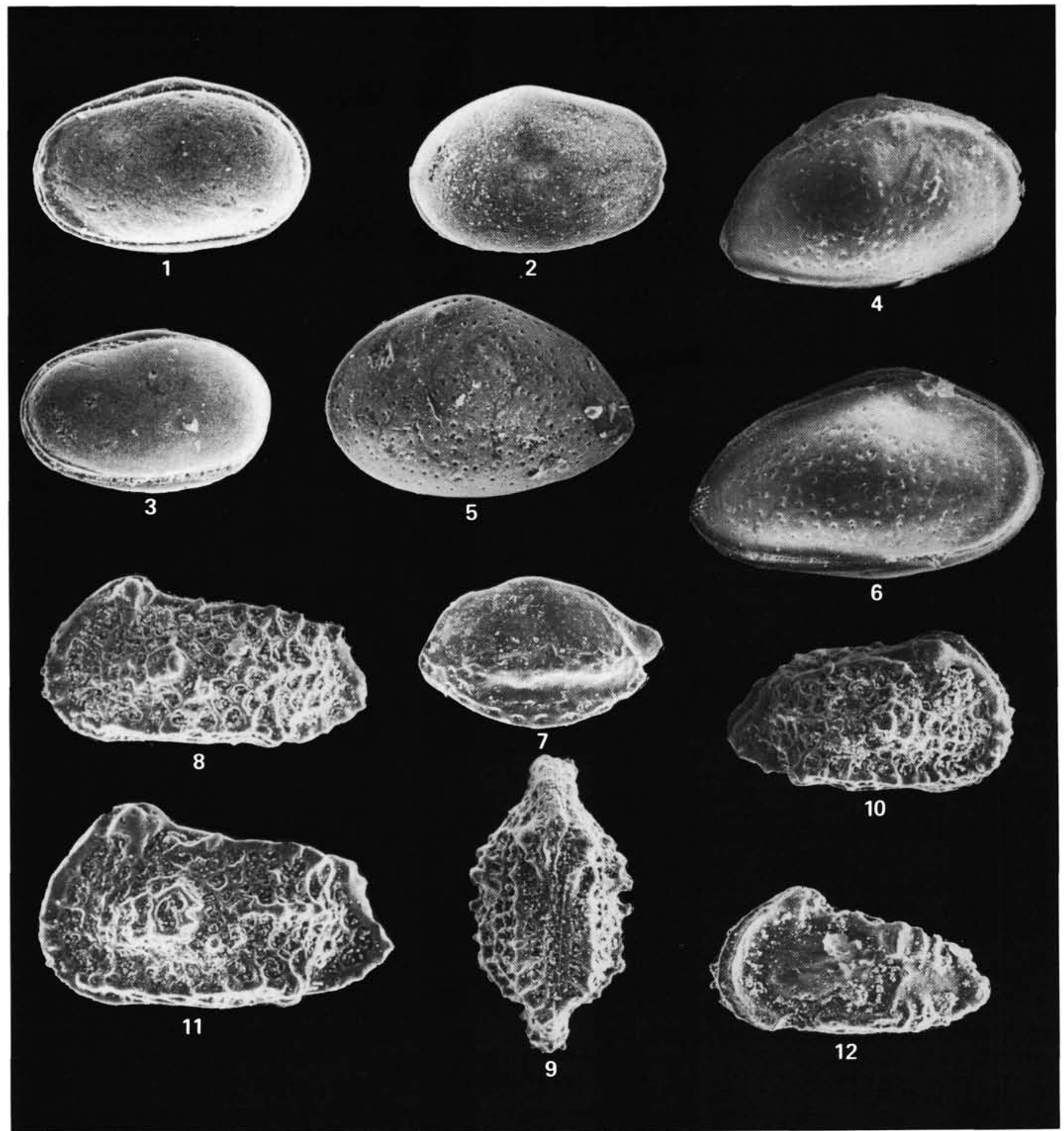

Plate 1. Cretaceous ostracodes, Leg 101. 1-3. Cytherella austinensis Alexander, 1929; $90 \times$; (1) carapace from the left; (2) right valve; (3) carapace from the left; $(1,2)$ Sample 101-627B-43X-3, 15-17 cm; (3) Sample 101-627B-39X-3, 50-52 cm. 4-6. Schuleridea washitaensis (Alexander, 1929); $75 \times$; (4) carapace from the right; (5) left valve; (6) carapace from the right; (4) Sample 101-627B-53X-CC; (5, 6) Sample 101-627B-47X-5, 50-52 $\mathrm{cm}$. 7. Cytheropteron (Eocytheropteron) jugosum Alexander, 1933; 70 $\times$; left valve, Sample 101-627B-38X-6, 50-52 cm. 8-11. Cythereis (Cythereis) fredericksburgoides Swain and Brown, 1964; 75 $;$; 8 carapace from the left; (9) carapace, dorsal view; (10) carapace from the right; (11) carapace from the left; (8-10) Sample 101-627B-43X-3, 15-17 cm; (11) Sample 101-627B-47X-5, 50-52 cm. 12. Cythereis (Cythereis) cf. pittensis Swain and Brown, 1964; 75×; left valve, Sample 101-627B-38X-6, 50-52 cm. 


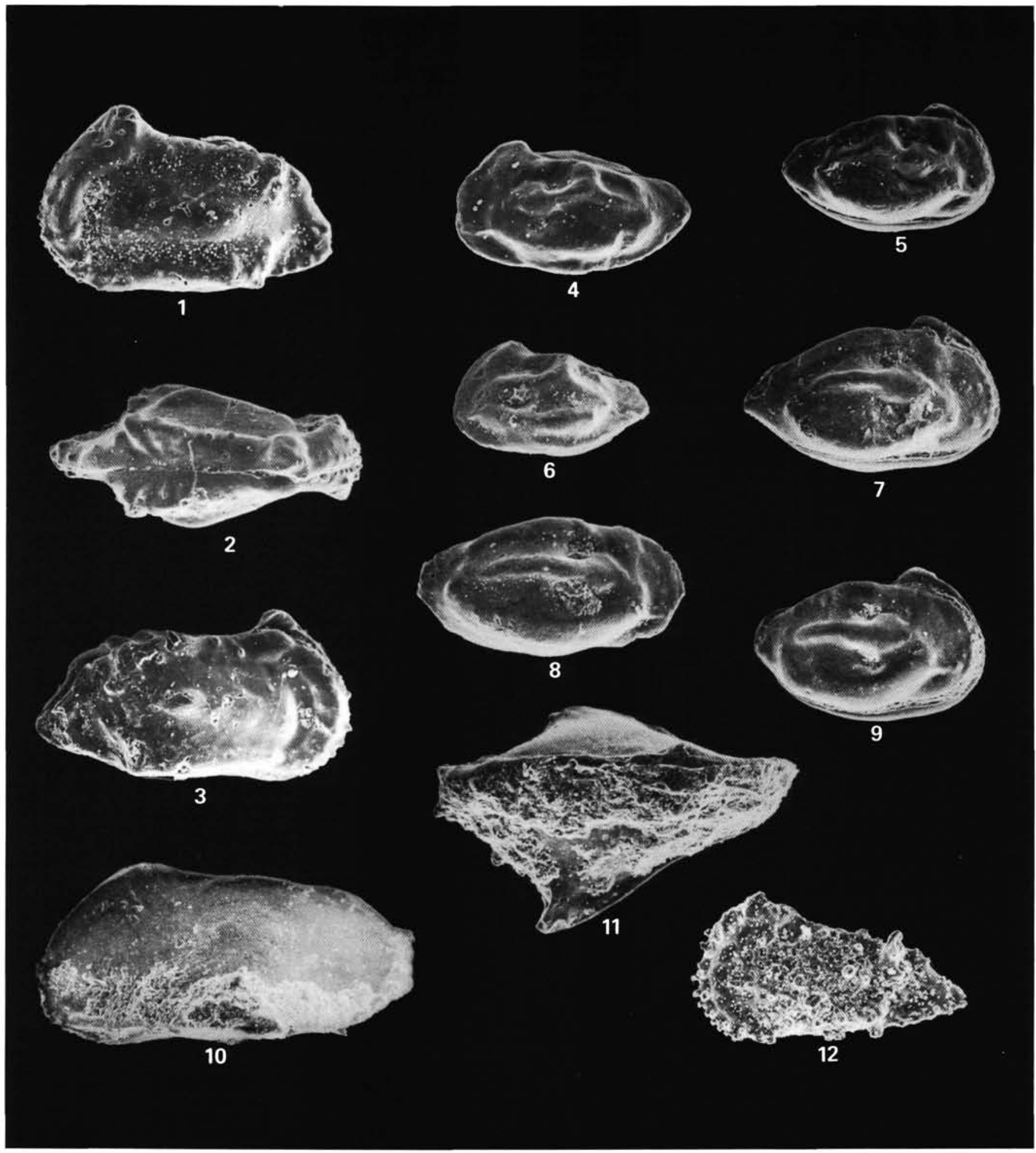

Plate 2. Cretaceous ostracodes, Leg 101. 1-3. Cythereis (Rehacythereis) simunoluda Swain, 1952; 75×; (1) carapace from the left; (2) carapace, dorsal view; (3) carapace from the right; (1-3) Sample 101-627B-43X-3, 15-17 cm. 4-6. Protocythere alexanderi Howe and Laurencich, 1958; 90×; (4) carapace from the left; (5) carapace from the right; (6) carapace from the left; $(4,5)$ Sample 101-627B-43X-3, 15-17 cm; (6) Sample 101-627B$39 \mathrm{X}-3,50-52 \mathrm{~cm}$. 7-9. Protocythere paratriplicata Swain, 1952; $90 \times$; (7) carapace from the right; (8) right valve; (9) carapace from the right; (7) Sample 101-627B-47X-5, 50-52 cm; (8, 9) Sample 101-627B-39X-3, 50-52 cm. 10-11. Pterygocythereis cf. $P$. tokiana (Israelsky, 1929) sensu Swain, $1952 ; 75 \times$; (10) carapace from the left; $(11)$ carapace, dorsal view; $(10,11)$ Sample 101-627B-46X-5, $50-53 \mathrm{~cm}$.) 12. Isocythereis(?) sp; $90 \times$; carapace from the left; Sample 101-627B-38X-5, 50-52 cm. 